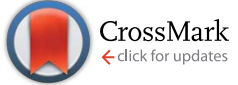

Cite this: RSC Adv., 2017, 7, 13904

Received 23rd December 2016 Accepted 13th February 2017

DOI: $10.1039 / c 6 r a 28630 e$

rsc.li/rsc-advances

\title{
Natural phosphorus-doped honeycomb carbon materials as oxygen reduction catalysts derived from Pulsatilla chinensis (Bunge) Regel
}

\begin{abstract}
Lei Zhao*ab
Facile phosphorus (P)-doped carbon materials based on Pulsatilla chinensis (Bunge) Regel (PCR) were directly used in oxygen reduction reaction (ORR). The half-peak potential of PCR carbonized at $1000{ }^{\circ} \mathrm{C}$ (PCR-1000) was $30 \mathrm{mV}$ lower than that of the commercial Pt/C (20\%) catalysts. The PCR-1000 showed $87.0 \%$ of the initial current density after $20000 \mathrm{~s}$ stable testing at the rotation of $1600 \mathrm{rpm}$ in $\mathrm{O}_{2^{-}}$ saturated $0.1 \mathrm{M} \mathrm{KOH}$. This study provides a method for the preparation of P-doped ORR catalysts derived from biomass. In addition, the honeycomb structure carbon materials can also provide a carrier for other applications including composite catalysts in fuel cells and electrode materials in supercapacitors.
\end{abstract}

\section{Introduction}

Fuel cells are considered as a renewable energy technology and have been widely researched in recent years for their merits of high energy density and zero emission. ${ }^{1}$ However, the progress of fuel cells is limited due to the sluggishness of the ORR in the cathode. ${ }^{2,3}$ At present, platinum and its alloys are the most effective ORR catalysts. However, their applications are restricted because of their high-cost. Therefore, the development of inexpensive and alternative cathodic catalysts is desirable in the area of fuel cells. Based on these conditions, many researchers developed many metal-free catalysts. Nitrogen-doped carbon materials were extensively used for their high ORR activity in ORR since the first report of high ORR activity of vertically aligned N-doped carbon nanotubes by Dai and co-workers in 2009. ${ }^{4}$ Phosphorus has the same number of valence electron as nitrogen; in addition, the larger atomic size and lower electronegativity of $\mathrm{P}$ can introduce a defectinduced active surface and local charge density through its lone pair electrons in the $3 p$ orbital, which should be facilitated by $\mathrm{O}_{2}$ adsorption in the ORR., ${ }^{\mathbf{1 , 5}}$ However, the development of P-doped carbon materials in ORR is sluggish compared with the quick development of nitrogen-doping. Recently, some phosphorus sources such as phosphate, ${ }^{6}$ triphenylphosphine, ${ }^{7-9}$ phosphoric acids, ${ }^{10-12}$ and ionic liquid ${ }^{13}$ were used for P-doped carbon materials. P-doped graphite layers and P-doped graphitic carbon nanospheres all exhibited high electrocatalytic activity. However, their tedious synthesis process and low P-doped content restricted their industrial applications. Although different chemical methods were used for the preparation of P-doped catalysts, the

a Department of Chemistry, Tsinghua University, Haidian District, Beijing 100084, China. E-mail: leizhao_qinghua@sina.com; Tel: +86-755-26036729

${ }^{b}$ Graduate School at Shenzhen, Tsinghua University, University Town, Nanshan District, Shenzhen 518055, China results were unsatisfactory for difficult doping and not retaining the P element at high temperature. Apart from this point, Strelko et al. researched the mechanism of the influence of $\mathrm{P}$ doping in a carbon matrix and, from a theoretical study of the band gap energy, found that the dopant content was related to the catalytic activity. ${ }^{14}$ We found that the content with better ORR catalytic effects in P-doped carbon materials was not larger than 3 at\% in many previous reports. Based on these two reasons, we considered to realize P-doping from biomass. ${ }^{5-13,15}$ Biomass has many nutrients including different elements, especially $\mathrm{P}$ that is very important for biomass growth. $\mathrm{P}$ in the biomass is contained in various structures, which may contribute to increasing the diversity of Pdoping. We considered that the natural P-doping in biomass may obtain the uniform structures and different phosphorus groups. At present, there are few reports on the P-doped catalysts from biomass including yeast cells ${ }^{5}$ and coconut shells ${ }^{15}$ as precursors.

Herein, we reported facile P-doped carbon materials used in ORR for the first time. The PCRs in this study were obtained from Xiao Hinggan Mountains in the northeast of China, which were distributed in hills, slopes or fields. The carbonization of the PCR biomass material is a low-cost, simple, and readily scalable approach for the synthesis of P-doped honeycomb carbon materials. In this study, the larger phosphorus content in the carbonization of the PCR biomass was 1.46 at\%, which was compared with the contents obtained from chemical P-doping methods. Moreover, the carbonized PCR exhibited superior properties in the ORR. The half-peak potential of PCR-1000 was $30 \mathrm{mV}$ lower than that of the commercial Pt/C (20\%) catalyst, and $87.0 \%$ of the initial current density was maintained after $20000 \mathrm{~s}$ of stable testing at the rotation of $1600 \mathrm{rpm}$ in $\mathrm{O}_{2}$-saturated $0.1 \mathrm{M} \mathrm{KOH}$. These results demonstrated that the method derived from the P-doped biomass materials not only demonstrated superior properties in ORR but 
also showed the implementation of a novel idea for the difficult preparation of P-doped catalysts in fuel cells.

\section{Experimental}

PCR was obtained from Xiao Hinggan Mountains in the northeast of China (Fig. 1). The PCR biomass was dried at $100{ }^{\circ} \mathrm{C}$ for $12 \mathrm{~h}$ before heat treatment. The dried PCR was put in a tube furnace and then heated at $400{ }^{\circ} \mathrm{C}$ for $1 \mathrm{~h}$. Subsequently, the obtained carbon materials were directly carbonized from 700 to $1000{ }^{\circ} \mathrm{C}$ for $1 \mathrm{~h}$ at the heating rate of $10{ }^{\circ} \mathrm{C} \mathrm{min}^{-1}$ in $\mathrm{N}_{2}$ atmosphere with the flow rate of $100 \mathrm{ml} \mathrm{min}^{-1}$. After carbonization, the samples were washed several times with distilled water and dried at $60^{\circ} \mathrm{C}$. PCRs carbonized at $700,800,900$, and $1000{ }^{\circ} \mathrm{C}$ were denoted as PCR-700, PCR-800, PCR-900, and PCR1000 , respectively.

Scanning electron microscopy (SEM, HITACHI S-4800), Transmission electron microscope (TEM, JEM-2100HR), and X-ray diffraction (XRD, Rigaku D/Max 2500/PC) were used to characterize the structure and morphology. X-ray photo electron spectroscopy (XPS, ESCALAB 250) was used to determine the

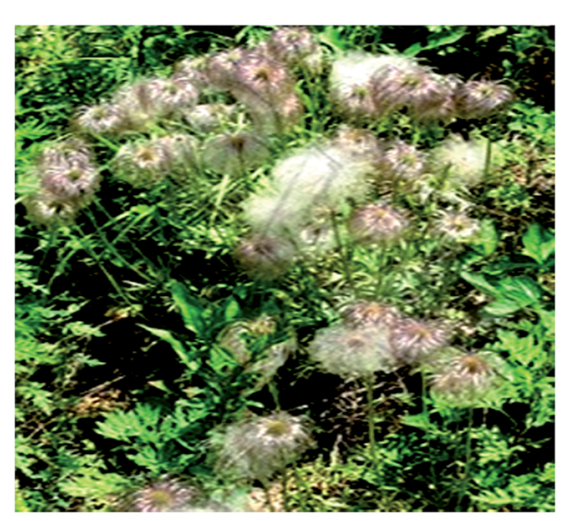

Fig. 1 The schematic for Pulsatilla chinensis (Bunge) Regel. composition. The electrochemical evaluation was carried out using an electrochemical workstation (RST5200F, Zhengzhou shiruisi Instrument Technology Co., Ltd. China). Cyclic voltammogram (CV) and rotating-disk electrode (RDE) polarization curves were obtained using a conventional three-electrode electrochemical system. Platinum wire (CHI115) and $\mathrm{Ag} / \mathrm{AgCl}$ (sat.) (CHI111) electrodes were used as the counter and reference electrodes, respectively. A disk ( $4 \mathrm{~mm}$ in diameter, 0.1256 $\mathrm{cm}^{2}$, Jiangsu Jiangfen Electroanalytical Instrument Co., Ltd.) was used as the working electrode to test the $\mathrm{CV}$ and $\mathrm{RDE}$ curves. Before measurements, the glassy carbon (GC) electrode was polished with gamma alumina powders $(0.05 \mathrm{~mm})$ until a mirror-like surface was obtained, and then washed twice with distilled water and dried in a vacuum. PCR catalysts $(12.5 \mathrm{mg})$ were put in an ethanol solution $(1 \mathrm{ml})$ and were treated by ultrasonication for 20 minutes. Then, $2 \mu \mathrm{l}$ solution was placed on the surface of the GC electrode to achieve a content of $200 \mu \mathrm{g}$ $\mathrm{cm}^{-2}$. Finally, a drop of Nafion solution ( $5 \mathrm{wt} \%$, DuPont) was placed onto the abovementioned surface for improving the adhesion of active materials and the GC electrode surface. The $\mathrm{RDE}$ polarization curves were measured by the reference electrode of $\mathrm{Ag} / \mathrm{AgCl}$ (sat.) in a $0.1 \mathrm{M} \mathrm{KOH}$ solution at the scan rate of $10 \mathrm{mV} \mathrm{s}^{-1}$ and rotation rates from 400 to $3600 \mathrm{rpm}$. CV curves were measured in the same range. $\mathrm{O}_{2}$ was bubbled into the cell for $30 \mathrm{~min}$ to obtain $\mathrm{O}_{2}$-saturated solutions before the measurements. To eliminate the influence of the background current, the $\mathrm{CV}$ and RDE curves were also tested in $\mathrm{N}_{2}$-saturated solution. The current-time $(i-t)$ curves were measured at the constant potential of $-0.40 \mathrm{~V}$ in $0.1 \mathrm{M} \mathrm{KOH}$ solution for $20000 \mathrm{~s}$ under continuous $\mathrm{O}_{2}$ bubbling with a flow rate of $20 \mathrm{ml} \mathrm{min}^{-1}$ at the fixed rotation rate of $1600 \mathrm{rpm}$.

\section{Results and discussion}

Two different structures were shown in Fig. 2. Honeycomb structures of PCR-700, PCR-800, and PCR-1000 carbon materials
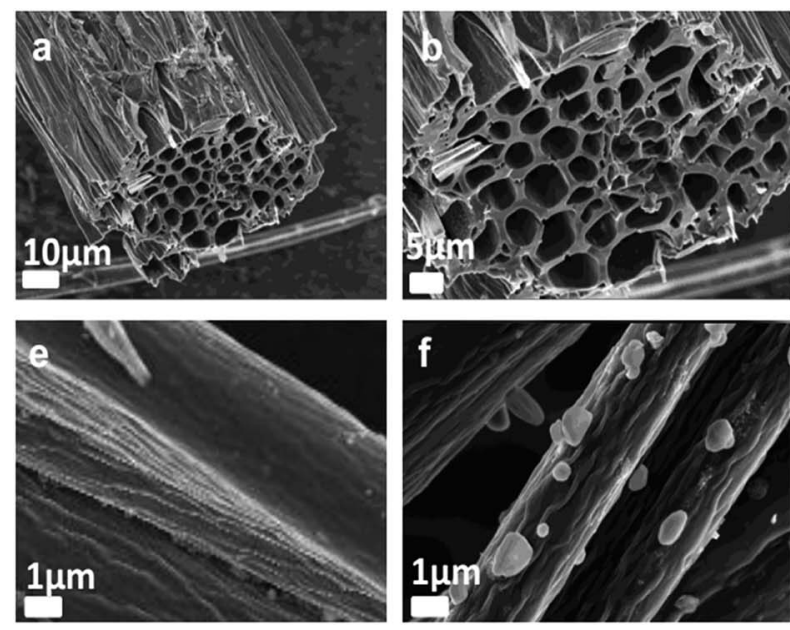
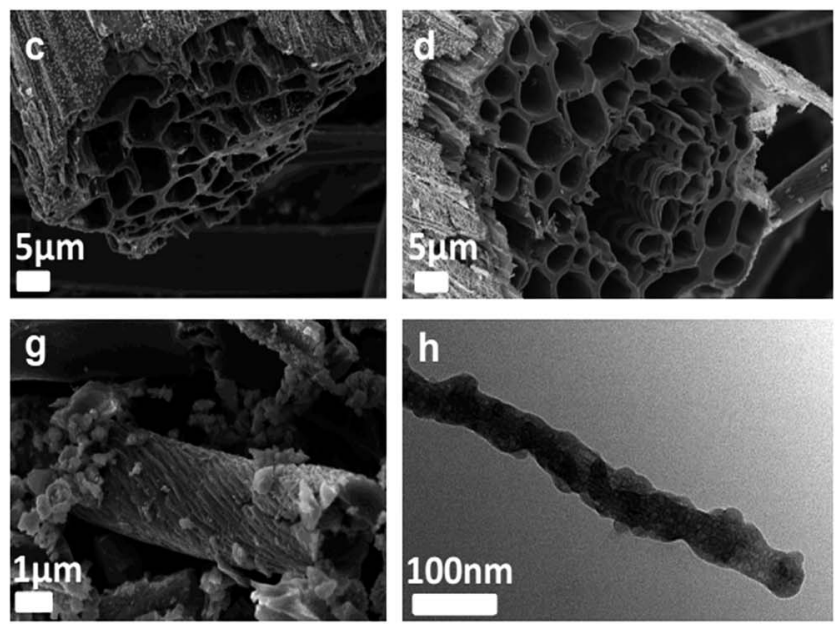

Fig. 2 SEM images: low magnification of PCR-700 (a), middle magnification of PCR-700 (b), middle magnification of PCR-800 (c), middle magnification of PCR-1000 (d), fiber structure of PCR-700 (e), fiber structure of PCR-800 (f), fiber structure of PCR-900 (g),TEM image: fiber structure of PCR-1000 (h). 
were shown in Fig. $2 \mathrm{a}$ and b, and Fig. $2 \mathrm{c}$ and d, respectively. Fig. $2 \mathrm{~b}$ was the enlargement of Fig. 2a, showing the honeycomb structure. With the increasing temperature, the surface of the honeycomb structures showed more particles, which can be reflected from the mapping images shown in Fig. 3, indicating some metal elements. Apart from the honeycomb structures, fiber structures were also observed (Fig. 2e-h), and the diameter of PCR carbon materials gradually decreased with the increasing carbonized temperature. As compared to the fibers of PCR-700 and PCR-800, PCR-900 showed more flexural folds and particles at the surface of the fibers (Fig. 2g). The diameter of honeycomb pores and the wall thicknesses are from $1 \mathrm{~nm}$ to $10 \mu \mathrm{m}$ and from $500 \mathrm{~nm}$ to $2 \mu \mathrm{m}$, respectively (Fig. $2 \mathrm{~b}-\mathrm{d}$ ). Apart from this, more particles on the PCR-1000 surface, as shown in Fig. 2h, were present in the TEM image, which can be seen clearly from its illustration corresponding to the position of the elemental mapping images of PCR-1000. Fig. 3 revealed the corresponding elemental compositions including $\mathrm{C}, \mathrm{O}, \mathrm{P}, \mathrm{Ca}$, and $\mathrm{K}$, in which $\mathrm{P}$ and $\mathrm{O}$ are distributed in the interior of PCR1000. As shown in Fig. 4, two obvious peaks of PCR carbon materials corresponded to the (002) and (100) reflections. Distance spaces of PCR-700, PCR-800, PCR-900, and PCR-1000 are $0.357,0.362,0.362$, and $0.364 \mathrm{~nm}$, respectively. With the increasing temperature, the degree of crystallinity of PCR carbon materials gradually decreased. The large peak width and absence of the peaks related to the interlayer order were due to the presence of defects. ${ }^{16}$ Usually, with the increasing temperature, the degree of crystallinity of carbon materials increased, but the PCR series carbon materials presented the opposite results, which can be understood by the high percentage of the edge orientation. Otherwise, the $\mathrm{P}$ content had a great influence on the structure of the PCR-1000, which adopted a more disordered structure corresponding to the results of XPS. Compared with other samples, PCR-1000 exhibited more defects, which facilitated the improvement of the conductivity and increased the catalytic sites. Raman spectra of PCR-700, PCR-800, PCR-900, and PCR-1000 are shown in Fig. 5. All spectra exhibited the well-known D-band and G-band peaks associated with the disordered and graphitized structures, respectively. ${ }^{17,18}$ The ratios of the D-band and G-band in terms of

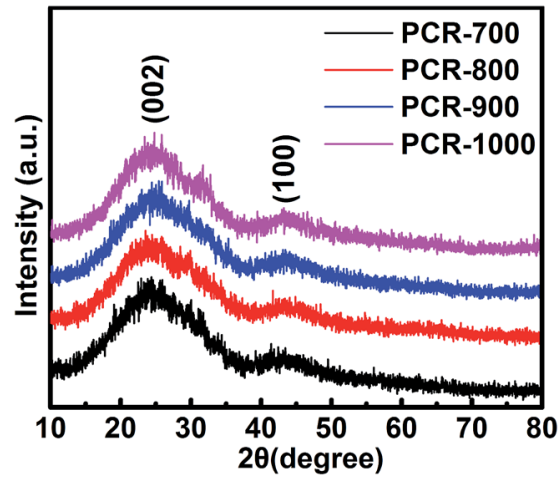

Fig. 4 XRD patterns of PCR-700, PCR-800, PCR-900, and PCR-1000.

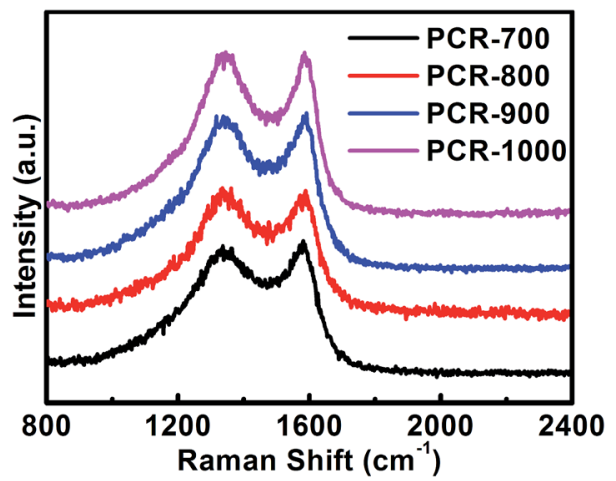

Fig. 5 Raman spectra of PCR-700, PCR-800, PCR-900, and PCR1000.

intensity $\left(I_{\mathrm{D}} / I_{\mathrm{G}}\right)$ for PCR-700, PCR-800, PCR-900, and PCR-1000 are $3.05,3.11,2.94$, and 3.28 , respectively. Generally, the $I_{\mathrm{D}} / I_{\mathrm{G}}$ ratio decreased with the increasing carbonized temperature, suggesting the improvement of the crystallinity. The $I_{\mathrm{D}} / I_{\mathrm{G}}$ gradually decreased until PCR-900, but PCR-1000 $I_{\mathrm{D}} / I_{\mathrm{G}}$ reached the largest value in the Raman spectrum, suggesting more disorder structures, which was agreement with the XRD results.

The XPS survey revealed the presence of $\mathrm{C}, \mathrm{O}, \mathrm{P}, \mathrm{N}, \mathrm{Ca}$, and $\mathrm{K}$ on the surface of PCR carbon materials in Fig. 6a. Table 1
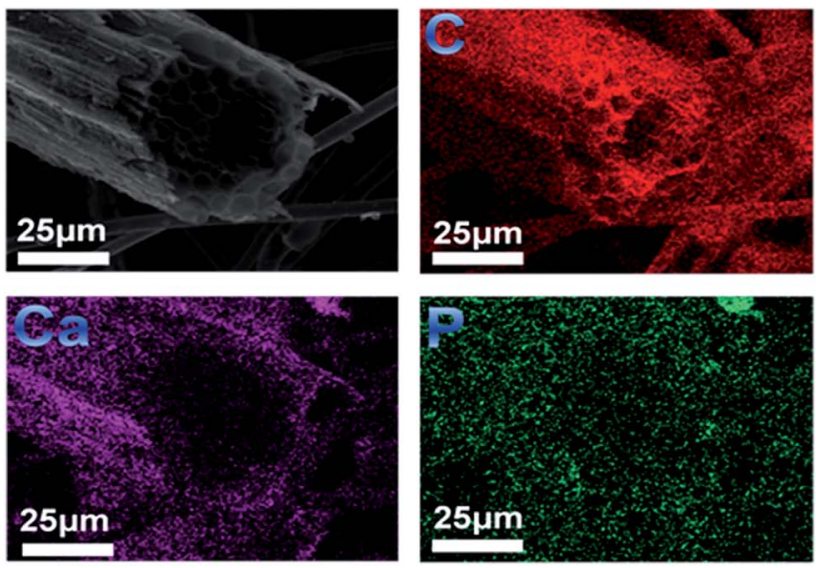
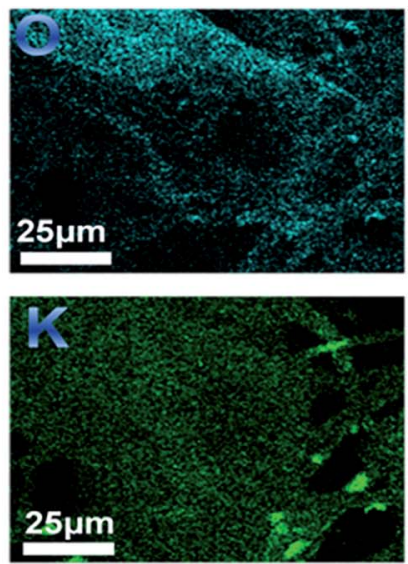

Fig. 3 Elemental mapping images of PCR-1000 including C, O, Ca, P, and K. 

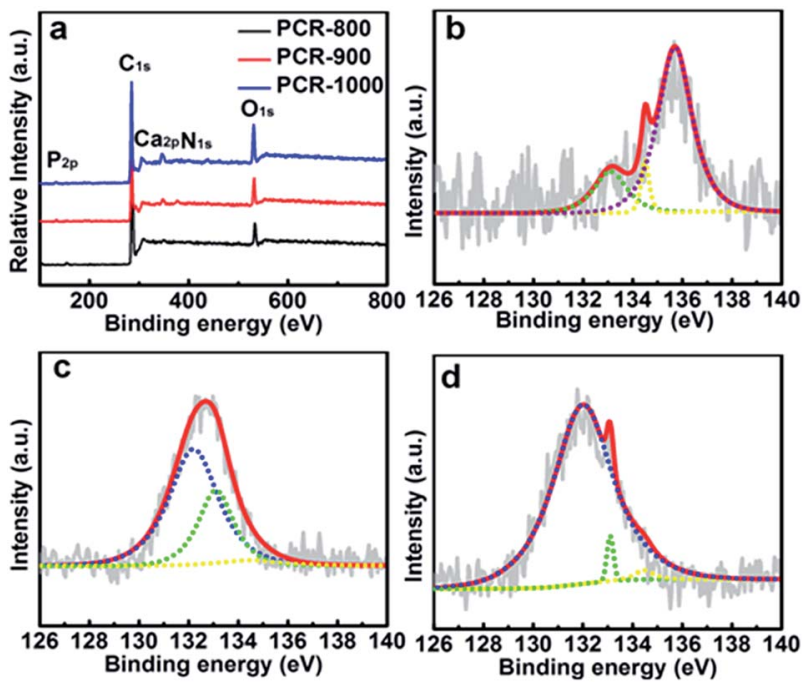

Fig. 6 (a) XPS survey of PCR-800, PCR-900, and PCR-1000. $P_{2 p}$ spectra of PCR-800 (b), PCR-900 (c), and PCR-1000 (d). Fitted lines, blue: $\mathrm{C}_{3} \mathrm{PO}$, green: $\mathrm{C}-\mathrm{PO}_{3}$, yellow: $\mathrm{C}-\mathrm{O}-\mathrm{PO}_{3}$, and pink: $\mathrm{P}-\mathrm{O}$.

summarizes the atomic surface concentrations of different catalysts. The contents of $\mathrm{O}, \mathrm{P}$, and $\mathrm{Ca}$ all increased with the carbonized temperature, whereas those of $\mathrm{C}$ and $\mathrm{N}$ gradually decreased. Note that significant amount of phosphorus (from 0.34 to $1.46 \mathrm{at} \%$ ) remained on the surface of the three catalysts. The thermal treatment increased the oxygen content from 8.95 to 14.45 at $\%$.

The $\mathrm{P}_{2 \mathrm{p}}$ spectrum of phosphorus for PCR biomass carbon had been reported as $\mathrm{C}_{3} \mathrm{PO}, \mathrm{C}-\mathrm{PO}_{3}, \mathrm{C}-\mathrm{O}-\mathrm{PO}_{3}$, and $\mathrm{P}-\mathrm{O}$ groups at the binding energy regions of $132.1,133.1,133.7-134.6$, and $135.7 \mathrm{eV}$, respectively. ${ }^{19-21}$ A peak at the value around $134.2 \mathrm{eV}$ was assigned to $\mathrm{P}$ groups bonded to a carbon site through an $\mathrm{O}$ atom $\left(\mathrm{C}-\mathrm{O}-\mathrm{PO}_{3}\right.$ and/or $\left.(\mathrm{C}-\mathrm{O})_{3} \mathrm{PO}\right){ }^{19,22-24} \mathrm{~A}$ second peak that appeared at the binding energy of about $133.1 \mathrm{eV}$ indicated the existence of $\mathrm{C}-\mathrm{P}$ bonding as in $\mathrm{C}-\mathrm{PO}_{3} \cdot{ }^{22-24} \mathrm{~A}$ small peak at

Table 1 Surface composition of different catalysts observed in the XPS spectra (at\%)

\begin{tabular}{llrllll}
\hline & \multicolumn{6}{l}{ Relative intensities of different elements (at\%) } \\
\cline { 2 - 7 } Catalyst & $\mathrm{C}$ & $\mathrm{O}$ & $\mathrm{P}$ & $\mathrm{N}$ & $\mathrm{Ca}$ & $\mathrm{K}$ \\
\hline PCR-800 & 88.45 & 8.95 & 0.34 & 0.32 & 1.58 & 0.36 \\
PCR-900 & 80.70 & 13.64 & 1.46 & 0.31 & 2.17 & 1.12 \\
PCR-1000 & 79.95 & 14.45 & 1.26 & 0.27 & 3.48 & 0.59
\end{tabular}

Table 2 Relative intensities of XPS P 2p spectra

\begin{tabular}{lllll}
\hline & \multicolumn{4}{l}{ Relative intensities of different peaks (at\%) } \\
\cline { 2 - 5 } Catalyst & $\mathrm{C}_{3} \mathrm{PO}$ & $\mathrm{C}-\mathrm{PO}_{3}$ & $\mathrm{C}-\mathrm{O}-\mathrm{PO}_{3}$ & $\mathrm{P}-\mathrm{O}$ \\
\hline PCR-800 & 0 & 18.43 & 5.65 & 75.92 \\
PCR-900 & 65.87 & 30.34 & 3.79 & 0 \\
PCR-1000 & 96.12 & 2.39 & 1.49 & 0
\end{tabular}
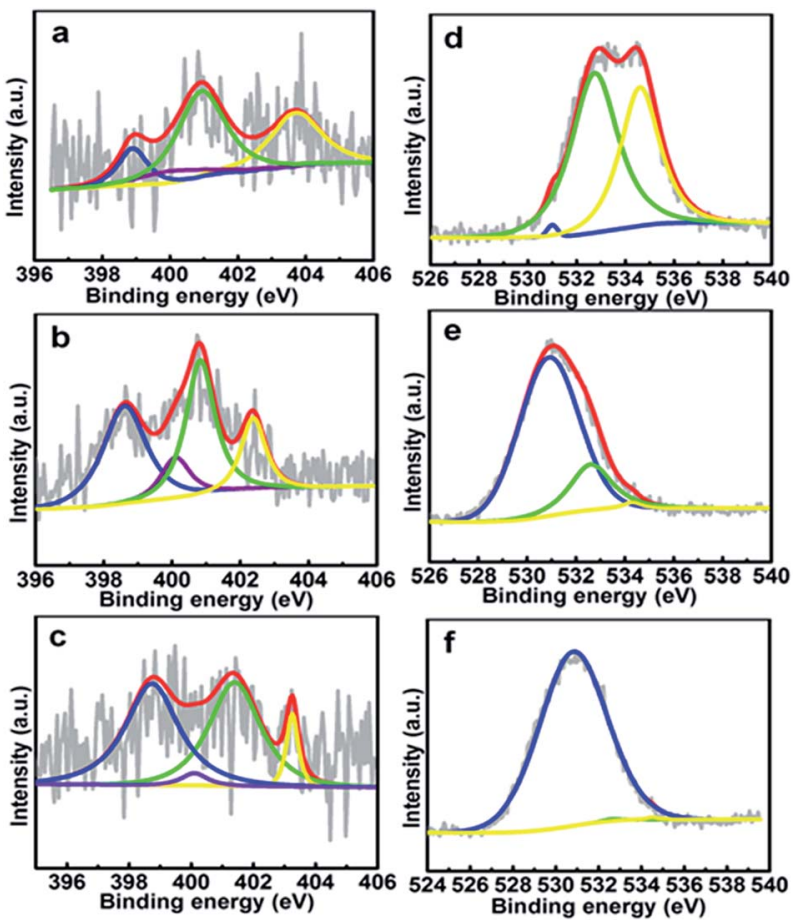

Fig. $7 \mathrm{~N}$ 1s spectra of PCR-800 (a), PCR-900 (b), and PCR-1000 (c), (blue: pyridinic- $\mathrm{N}$, violet: pyrrolic- $\mathrm{N}$, green: quaternary- $\mathrm{N}$, yellow: pyridine-N-O), O 1s spectra of PCR-800 (d), PCR-900 (e), and PCR1000 (f), blue: $=\mathrm{O}$ in carbonyl, carboxyl and phosphates, green: -O-, yellow: chemisorbed $\mathrm{O}$ and $\mathrm{H}_{2} \mathrm{O}$.

around $132.1 \mathrm{eV}$ was ascribed to $\mathrm{C}_{3} \mathrm{PO}$ groups and the peak at $135.7 \mathrm{eV}$ was related to $\mathrm{P}-\mathrm{O}$ groups. ${ }^{19,22-24}$ Similar peaks have been obtained for phosphoric acid-activated carbons from kraft lignin. $^{17,19}$ As shown in Table 2, the carbonization process caused a decomposition of the less stable $\mathrm{P}-\mathrm{O}$ groups and $\mathrm{C}-\mathrm{O}-$ $\mathrm{PO}_{3}$ groups, increasing the amount of $\mathrm{C}-\mathrm{PO}_{3}$ and $\mathrm{C}_{3} \mathrm{PO}$ groups. Phosphorus directly bonded to the edge carbon atoms in

Table 3 Relative intensities of XPS N 1s spectra

Relative intensities of different peaks (at\%)

\begin{tabular}{llclc} 
Catalyst & Pyridinic-N & Pyrrolic-N & Quaternary-N & Pyridinie-N-O \\
\hline PCR-800 & 12.31 & 8.70 & 47.81 & 31.18 \\
PCR-900 & 37.80 & 10.44 & 36.54 & 15.22 \\
PCR-1000 & 46.42 & 2.58 & 43.82 & 7.18
\end{tabular}

Table 4 Relative intensities of XPS O 1s spectra

\begin{tabular}{llrc}
\hline & \multicolumn{2}{l}{ Relative intensities of different peaks (at\%) } \\
\cline { 2 - 4 } Catalyst & $\begin{array}{l}\text { O in carbonyl } \\
\text { and carboxyl }\end{array}$ & $-\mathrm{O}-$ & $\begin{array}{l}\text { Chemisorbed } \\
\mathrm{O} \text { and } \mathrm{H}_{2} \mathrm{O}\end{array}$ \\
\hline PCR-800 & 0.85 & 57.18 & 41.97 \\
PCR-900 & 80.89 & 18.10 & 1.01 \\
PCR-1000 & 99.60 & 0.22 & 0.18
\end{tabular}


graphite via a $\mathrm{C}-\mathrm{P}-\mathrm{O}$ bond. ${ }^{25}$ The results of $\mathrm{P}_{2 \mathrm{p}}$ spectra were in agreement with the defects analysis of XRD and Raman.

The XPS $\mathrm{N}_{1 \mathrm{~s}}$ spectra of the three catalysts were divided into four groups. Fig. 7a-c correspond to PCR-800, PCR-900, and PCR-1000, respectively. The peaks were attributed to pyridinic-N at $398.7 \pm 0.3 \mathrm{eV}$, pyrrolic- $\mathrm{N}$ at $400.3 \pm 0.3 \mathrm{eV}$, quaternary- $\mathrm{N}$ at
$401.4 \pm 0.5 \mathrm{eV}$, and pyridinie- $\mathrm{N}-\mathrm{O}$ at $402-405 \mathrm{eV} .{ }^{26}$ In Table 3 , the variety of the four types is pyridinic- $\mathrm{N}$ and the proportion gradually increased from $12.31 \%$ to $46.42 \%$, which takes more active sites in the ORR.

The XPS $\mathrm{O}_{1 \mathrm{~s}}$ spectra of the three catalysts were divided into three groups. The peak at 530.6-530.9 eV was attributed to an
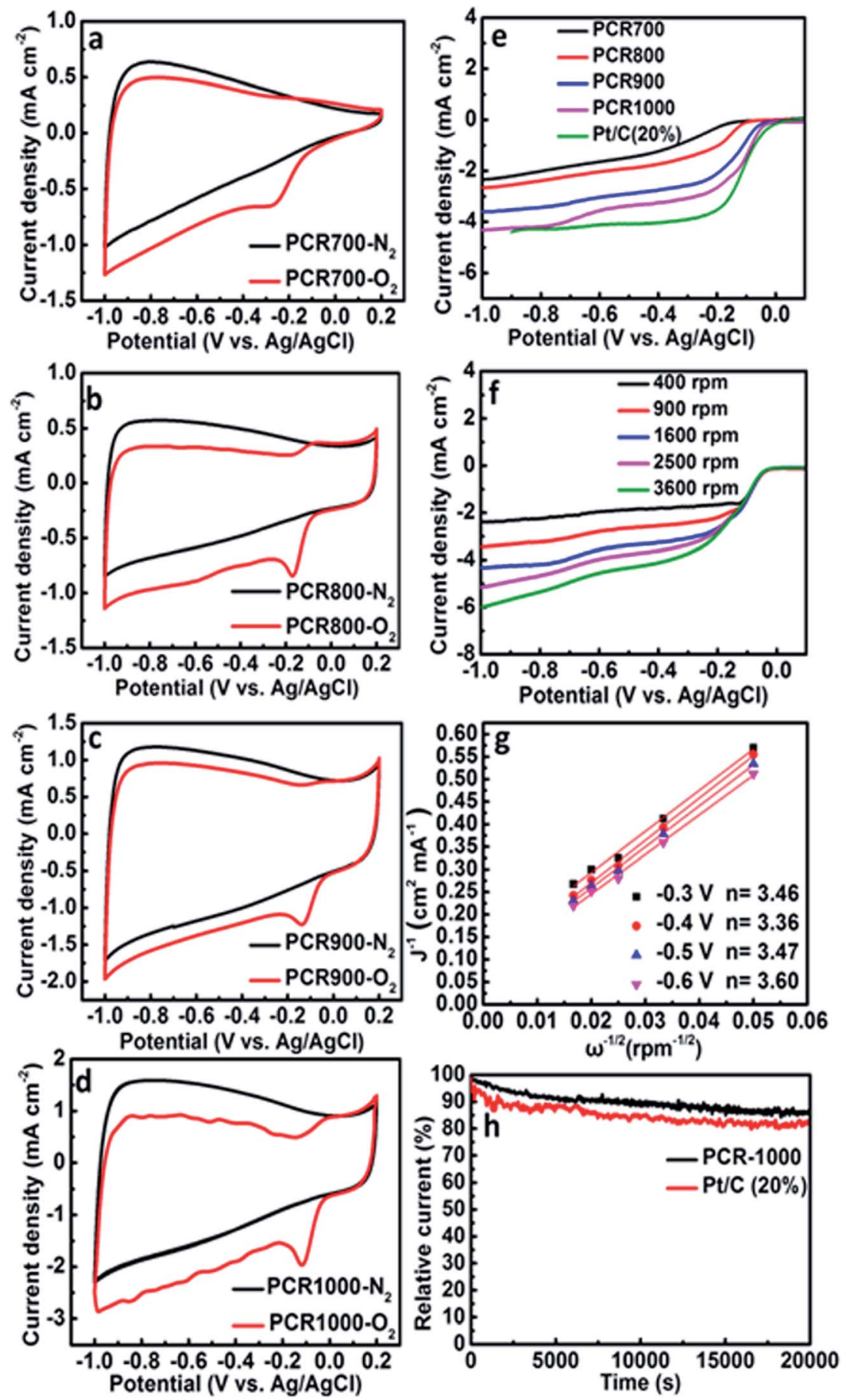

Fig. 8 Cyclic voltammograms (CV) curves of PCR-700 (a), PCR-800 (b), PCR-900 (c), and PCR-1000 (d) black line- $\mathrm{N}_{2}$, red line-O voltammograms of PCR-700, PCR-800, PCR-900, PCR-1000, and Pt/C catalysts at $1600 \mathrm{rpm}$ and $10 \mathrm{mV} \mathrm{s}^{-1}$ (e), polarization curves for ORR in an $\mathrm{O}_{2}$-saturated $0.1 \mathrm{M} \mathrm{KOH}$ solution on PCR-1000 electrodes with the rotation rates from 400 to 3600 rpm (f), Koutecky-Levich plots of the PCR-1000 electrode at different potentials and their corresponding electron transfer number (g), and current-time chronoamperometric response for PCR-1000 and Pt/C (20\%) catalysts tested at $-0.40 \mathrm{~V}$ vs. Ag/AgCl with the rotation speed of $1600 \mathrm{rpm}$ (h). 
oxygen doubly bonded to carbon $(\mathrm{C}=\mathrm{O})$ and non-bridging oxygen in the phosphate group $(\mathrm{P}=\mathrm{O}){ }^{27,28}$ The peak at 532.5$532.9 \mathrm{eV}$ was assigned to the combined effects of singly bonded oxygen (-O-) in $\mathrm{C}-\mathrm{O}$ and in $\mathrm{C}-\mathrm{O}-\mathrm{P}$ groups. The peak at 535.0$535.9 \mathrm{eV}$ was ascribed to the chemisorbed oxygen and water. With the increasing temperature, the $=\mathrm{O}$ group in the carbonyl and the -O- group and chemisorbed $\mathrm{O}$ groups decreased (Table 4), which was in accordance with the analysis results of the $\mathrm{P}_{2 \mathrm{p}}$ spectrum. $^{27,28}$

Compared to PCR-700, PCR-800, and PCR-900, the CV curve of PCR-1000 exhibited the largest ORR potential $(-0.120 \mathrm{~V} v s$. $\mathrm{Ag} / \mathrm{AgCl}$ ) (Fig. 8d) in an $\mathrm{O}_{2}$-saturated 0.1 $\mathrm{M} \mathrm{KOH}$ solution. On comparing the RDE curves of different catalysts obtained at the scan rate of $10 \mathrm{mV} \mathrm{s}^{-1}$ and at the rotation speed of 1600 rpm, as shown in Fig. 8e, it was observed that PCR-700, PCR-800, and PCR-900 catalysts showed relatively low ORR activity. On the contrary, PCR-1000 showed better electrocatalytic activity with the half-peak potential of $-0.137 \mathrm{~V} v s$. $\mathrm{Ag} / \mathrm{AgCl}$, which is $30 \mathrm{mV}$ lower than that of a commercial $\mathrm{Pt} / \mathrm{C}$ $(20 \%)$ catalyst, showing excellent potential in numerous $\mathrm{P}$ doped carbon materials. The half-peak current density was $2.18 \mathrm{~mA} \mathrm{~cm}^{-2}$, and the limited current densities were $4.36 \mathrm{~mA}$ $\mathrm{cm}^{-2}$ (Fig. 8e). RDE voltammograms of PCR-1000 catalyst at the rotation speeds from 400 to $3600 \mathrm{rpm}$ in an $\mathrm{O}_{2}$-saturated $0.1 \mathrm{M} \mathrm{KOH}$ solution are shown in Fig. 8f. Derived KouteckyLevich (K-L) plots (Fig. 8g) show the good linearity and parallelism, indicating that the ORR process of PCR-1000 follows first-order kinetics in the selected potential range from -0.3 to $-0.6 \mathrm{~V}$.

The electron transfer numbers $(n)$ during ORR and the kinetic limited current density $\left(J_{\mathrm{k}}\right)$ can be calculated from the following K-L equation: ${ }^{29}$

$$
1 / J=1 / J_{\mathrm{k}}+1 /\left(0.62 n F C_{0} D_{0}^{2 / 3} v^{-1 / 6} \omega^{1 / 2}\right)
$$

where $J$ is the measured current density $\left(\mathrm{mA} \mathrm{cm}^{-2}\right), J_{\mathrm{k}}$ is the kinetic limited current density $\left(\mathrm{mA} \mathrm{cm}{ }^{-2}\right), \omega$ is the angular velocity of the disk ( $\omega=2 \pi N, N$ is the linear rotation speed), $n$ is the overall number of electrons transferred per oxygen molecule during the ORR, $D_{0}$ is the diffusion coefficient $(\mathrm{cm}$ $\left.\mathrm{s}^{-1}\right), F$ is the Faraday constant $\left(F=96500 \mathrm{C} \mathrm{mol}^{-1}\right), C_{0}$ is the bulk concentration of $\mathrm{O}_{2}\left(\mathrm{~mol} \mathrm{~L}^{-1}\right), v$ is the kinematic viscosity of the electrolyte, $k$ is the electron transfer rate constant, and the values of $C_{0}, D_{0}$, and $v$ for an $\mathrm{O}_{2}$-saturated $0.1 \mathrm{M} \mathrm{KOH}$ solution are $1.14 \times 10^{-6} \mathrm{~mol} \mathrm{~cm}{ }^{-3}, 1.73 \times 10^{-5} \mathrm{~cm}^{2} \mathrm{~s}^{-1}$, and $0.01 \mathrm{~cm}^{2} \mathrm{~s}^{-1}$, respectively. The values of the $n$ and $J_{\mathrm{k}}$ can be estimated from the slope and intercept of the K-L plots, based on eqn (1). The values of the transferred electron number in the PCR-1000 catalyst are 3.46, 3.36, 3.47, and $3.60 \mathrm{e}$, which is involved in both a two and four electron transfer. ${ }^{4}$ The stability of PCR-1000 and Pt/C (20\%) catalysts were tested at the constant potential of $-0.4 \mathrm{~V}$ in an $\mathrm{O}_{2}$-saturated $0.1 \mathrm{M} \mathrm{KOH}$ solution at $1600 \mathrm{rpm}$ (Fig. 8h). After $20000 \mathrm{~s}$ of testing, PCR1000 maintained $87 \%$ of its initial current value, which was higher than $82.1 \%$ of the $\mathrm{Pt} / \mathrm{C}(20 \%)$ catalyst, indicating better stability than the $\mathrm{Pt} / \mathrm{C}$ catalyst in an $\mathrm{O}_{2}$-saturated $0.1 \mathrm{M} \mathrm{KOH}$ solution.

\section{Conclusion}

A facile method was used for the fabrication of phosphorusdoped honeycomb carbon materials as oxygen reduction catalysts derived from Pulsatilla chinensis (Bunge) Regel. The largest content of $\mathrm{P}$ in P-doped PCR biomass was 1.46 at\%, which corresponds to the value obtained via other chemical method. The pyridinic-N group gradually increased from $12.31 \%$ to 46.42\%, which takes more active sites in PCR-1000. PCR-1000 showed a better half-peak potential $(-0.137 \mathrm{~V}$ vs. $\mathrm{Ag} / \mathrm{AgCl})$, which was $30 \mathrm{mV}$ lower than that of the commercial $\mathrm{Pt} / \mathrm{C}$ $(20 \%)$ catalyst, showing excellent reactive potential in many previous P-doped carbon materials. In the PCR-1000 catalyst, the half-peak current density was $2.18 \mathrm{~mA} \mathrm{~cm}^{-2}$, and the limited current densities were $4.36 \mathrm{~mA} \mathrm{~cm}^{-2}$. The values of the transferred electron number in PCR-1000 catalyst were 3.46, 3.36, 3.47 , and 3.60 e including both two and four electron transfers. A value of $87.0 \%$ of the initial current density was maintained after $20000 \mathrm{~s}$ stable testing in an $\mathrm{O}_{2}$-saturated $0.1 \mathrm{M} \mathrm{KOH}$ solution with a rotation of $1600 \mathrm{rpm}$. The electrochemical testing results demonstrated that the method of P-doped materials derived from plants containing phosphorus exhibited superior properties in oxygen reduction, which implemented a novel idea for the preparation of difficult to prepare Pdoped carbon material catalysts in fuel cells.

\section{Acknowledgements}

The authors acknowledge the financial support received from the National Key Basic Research Program No. 2013CB933103 funded by MOST and the Program for the Fundamental Research Supported by Shenzhen Science and Technology Innovations Council of China (Grant No. JSF201006300047A, No. JC201105201126A, and No. ZDSY20120619140933512). The authors are grateful to the China Postdoctoral Science Foundation funded project, a project funded by China Postdoctoral Science (No. 2015M5811087).

\section{Notes and references}

1 L. Dai, Y. Xue, L. Qu, H. J. Choi and J. B. Baek, Chem. Rev., 2015, 115, 4823-4892.

2 M. K. Debe, Nature, 2012, 486, 43-51.

3 J. Masa, W. Xia, M. Muhler and W. Schuhmann, Angew. Chem., Int. Ed., 2015, 54, 10102-10120.

4 K. Gong, F. Du, Z. Xia, M. Durstock and L. Dai, Science, 2009, 323, 760-764.

5 X. Gong, S. Liu, C. Ouyang, P. Strasser and R. Yang, ACS Catal, 2015, 5, 920-927.

6 X. Sun, J. Xu, Y. Ding, B. Zhang, Z. Feng and D. S. Su, ChemSusChem, 2015, 8, 2872-2876.

7 C. Zhang, N. Mahmood, H. Yin, F. Liu and Y. Hou, Adv. Mater., 2013, 25, 4932-4937.

8 D.-S. Yang, D. Bhattacharjya, S. Inamdar, J. Park and J.-S. Yu, J. Am. Chem. Soc., 2012, 134, 16127-16130.

9 Z.-W. Liu, F. Peng, H.-J. Wang, H. Yu, W.-X. Zheng and J. Yang, Angew. Chem., 2011, 123, 3315-3319. 
10 Z. Chen, K. Li and L. Pu, Bioresour. Technol., 2014, 170, 379384.

11 J. Wu, Z. Yang, Q. Sun, X. Li, P. Strasser and R. Yang, Electrochim. Acta, 2014, 127, 53-60.

12 R. Li, Z. Wei, X. Gou and W. Xu, RSC Adv., 2013, 3, 99789984.

13 Z. Chen, K. Li, P. Zhang, L. Pu, X. Zhang and Z. Fu, Chem. Eng. J., 2015, 259, 820-826.

14 V. V. Strelko, V. S. Kuts and P. A. Thrower, Carbon, 2000, 38, 1499-1503.

15 M. Borghei, N. Laocharoen, E. Kibena-Poldsepp, L.-S. Johansson, J. Campbell, E. Kauppinen, K. Tammeveski and O. J. Rojas, Appl. Catal., B, 2017, 204, 394-402.

16 L. Zhao, Y. Qiu, J. Yu, X. Deng, C. Dai and X. Bai, Nanoscale, 2013, 5, 4902-4909.

17 F. Tuinstra and J. L. Koenig, J. Chem. Phys., 1970, 53, 11261130.

18 R. J. Nemanich and S. A. Solin, Phys. Rev. B: Condens. Matter Mater. Phys., 1979, 20, 392-401.
19 J. Bedia, J. M. Rosas, J. Rodríguez-Mirasol and T. Cordero, Appl. Catal., B, 2010, 94(1), 8-18.

20 M. Cuisinier, N. Dupré, J. F. Martin, R. Kanno and D. Guyomard, J. Power Sources, 2013, 224, 50-58.

21 X. Wu and L. R. Radovic, Carbon, 2006, 44, 141-151.

22 A. M. Puziy, O. I. Poddubnaya and A. M. Ziatdinov, Appl. Surf. Sci., 2006, 252, 8036-8038.

23 J. M. Rosas, J. Bedia, J. Rodrıguez-Mirasol and T. Cordero, Ind. Eng. Chem. Res., 2008, 47, 1288-1296.

24 Y.-J. Lee and L. R. Radovic, Carbon, 2003, 41, 1987-1997.

25 S. G. Oh and N. M. Rodriguez, J. Mater. Res., 1993, 8, 28792888.

26 D. Long, J. Zhang, J. Yang, Z. Hu, G. Cheng, X. Liu, R. Zhang, L. Zhan, W. Qiao and L. Ling, Carbon, 2008, 46, 1253-1269.

27 A. G. Kannan, N. R. Choudhury and N. K. Dutta, Polymer, 2007, 48, 7078-7086.

28 P. Y. Shih, S. W. Yung and T. S. Chin, J. Non-Cryst. Solids, 1999, 244, 211-222.

29 C. Jin, F. Lu, X. Cao, Z. Yang and R. Yang, J. Mater. Chem. A, 2013, 1, 12170-12177. 